but also indexed for ready reference. Under these circumstances the editor and author considered a special glossary to be superfluous.

Secondly, your reviewer is mistaken in describing the lettering of fig. 91, p. 143, as the result of undigested compilation. The interpretation of the squamosal and supratemporal bones in the Squamata there given, is intentional, and based especially upon the researches of my colleague, Mr. Boulenger. Anyone interested in the subject may refer to the figures of the skulls of the Agamoid Calotes and the typical Varanoid, Varanus, given in his volume on Reptiles and Batrachians contributed to Dr. Blanford's "Fauna of British India." He seems to demonstrate clearly that in Lacertilia the squamosal always retains its normal connection with the postfrontal in front, but eventually separates from the parietal behind; while the supratemporal in that case slips backward to occupy the cleft thus formed.

I am much indebted to your reviewer for pointing out that the legend of fig. 185 (Palaotherium) only applies to the true molars, not to the fourth premolar, which, I had omitted to observe, bears the same lettering. In the matter of new illustrations, I have met with unusually liberal treatment at the hands of the publishers ; but it was unfortunately impossible to dispense with borrowed electrotypes, and hence the non-uniformity of lettering which is sometimes perplexiug.

A. Smith Woonward.

\title{
OBITUARY.
}

\section{JAMES HALL.}

Bors SepteMber 12, 1811.

Died August 7, 1898.

By the death of Professor James Hall geology bas lost its oldest and one of its most distinguished leaders. He was born at the quaint old town of Hingham on the south shore of Boston Bay, and was educated at the Rensselaer Polytechnic Institute at Troy, and at the age of twenty-five received an appointment on the Geological Survey of New York State. Two years later he issued his first original scientific contribution, $\rightarrow$ a short note on some trilobites. His official duties were connected with both stratigraphy and palæontology, and at first he was apparently more interested in the former branch of geology. He studied the recession of the Niagara Falls and acted as guide to Lyell, who visited the Falls in 1841. In 1843 Hall was appointed State Palæontologist, in which capacity he wrote or edited no fewer than thirteen large imperial quarto volumes on the Palæontology of New York, which bave been issued at intervals between 1847 and 1894. The first volumes of this series formed the most magnificent contribution to extra-European Palæontology that had been issued at that time, and some of the later volumes are still the richest mine of information on some branches of Devonian palæontology. In addition to the extensive series of new fossils described in these monographs, Hall published many further important additions to American Palæontology in the reports of other State Surveys, as of Iowa, Wisconsin, and Missouri, and in papers in various 
serials. The collections of many of the early expeditions in the Western States were entrusted to Hall for description; thus he described the Cretaceous fossils collected by the Mexican Boundary Commission, the Carboniferous Crinoids of Missouri, the general collections of the Pacific Railway Survey, and he wrote the appendix on the geology and palæontology of the Great Salt Lake of Utah, from materials brought back by the Stansbury expedition. The number of interesting fossils which it was Hall's privilege to describe is enormous, and the following are a few of the well-known and important genera we owe to him: Among the graptolites there are Callograptus, Dicranograptus, and Phyllograptus; among the corals, Colophyllum, Heliophyllum, and Streptelasma; among the Pelmatozoa, Calceocrinus, Heterocrinus, Dendrocrinus, Glyptaster, Glyptocrinus, and Hemicystis ; there is the star-fish Palcaster, and the echinid Lepidechinis; the additions to the Monticuliporoids and Bryozoa are very numerons, including Favistella, Callopora, Bactropora, and Trematopora; and among the Crustacea are Pleuronotus, Bathynotus, Mesothyra, and Ptychaspis. His Memoir on North American Eurypterida, Pterygoti, and Ceratiocaris (1871), is one of the most valuable contributions to these forms of Crustacea. The number of his additions to the Palæozoic mollusca and Brachiopods reminds us of Disraeli's account of how Charlemagne made Christians, for Hall founded new genera in legions and christened them in platoons. But Hall was not only a palæontographer; his papers on the microseopic structure of Palæozoic brachiopod shells, and his discovery and description of the convoluted plate that supports the digestive tube in crinoids, show that he paid attention to anatomy. He was also keenly interested in the broader questions of stratigraphical geology. It was Hall who in 1859 first definitely stated the connection between the elevation of mountain chains and the previous accumulation of sedimentary deposits, and argued that "the direction of any mountain chain corresponds with the original line of greatest accumulation."

Among other palæontological contributions not connected with his own State, Hall described the Graptolites for the Canadian Survey; and owing to his especially friendly relations with the Canadian geologists he was appropriately chosen President of the American Association for the Advancement of Science when it met at Montreal in 1857. He was elected on the list of Foreign Members of the Geological Society in 1848, and received the Wollaston Medal from that Society in 1858, and as the doyen of American geologists was elected the first President of the Geological Society of America in 1889. In spite of his great age, he last year visited the Ural Mountains with the International Geological Congress, and, aided by J. M. Clark, he has continued his palæontological studies to the last. Professor Hall's courtesy, energy, and cheeriness endeared him to all with whom he was brought in contact, and his personal popularity frequently proved of great service to the State Survey, as wheu its work was harassed by the faction fights over the Erie Canal, or when the department was attacked by the State Librarian, Mr. Melvil Dewey, in 1895. 